\title{
Tree guild composition of a hill dipterocarp forest in West Sumatra, Indonesia
}

\author{
Tsuyoshi YONEDA ${ }^{1, *}$, Sen NISHIMURA ${ }^{2}$, Shinji FUJII ${ }^{3}$ and Erizal MUKHTAR ${ }^{4}$ \\ ${ }^{1}$ Faculty of Agriculture, Kagoshima University, 890-0065, Kagoshima, Japan \\ ${ }^{2}$ Forestry and Forest Products Research Institute, 305-8687, Tsukuba, Japan \\ ${ }^{3}$ University of Human Environments, 444-3505, Okazaki, Japan \\ ${ }^{4}$ Faculty of Mathematics and Science, Andalas University, Padang, Indonesia \\ * Corresponding author: yoneda@agri.kagoshima-u.ac.jp
}

\begin{abstract}
The guild composition of a hill dipterocarp forest was examined using growth traits of 1566 trees comprising 422 species through field observation at a 6-ha plot for 6 years in Sumatra. Three parameters, intrinsic growth rate, attainable maximum stem diameter, and stem hardness, were used for guild determination. The intrinsic growth rate showed a significant correlation with stem hardness, which suggested a trade-off between volume growth and architectural strength under the restraint of photosynthetic products. Four major guilds were determined, characterized as Soft wood-Small size-Fast growth, Soft-Big-Fast, HardBig-Slow, and Hard-Small-Slow traits. Ecological niches of these guilds were related to the large variance of resources in time and space of a tropical rain forest. A secondary forest part in the 6-ha plot retained high species diversity, but species composition was largely different from that of the mature stand. Human activities biased guild composition to reinforce the Soft-Small-Fast guild, with a reduction in the Hard-Big-Slow guild that included many marketable timber trees. Logging impacts on dipterocarp and fagaceous trees were assessed with reference to their spatial distribution and attributes of guilds.
\end{abstract}

Key words: attainable maximum tree size, climax species, guild composition, intrinsic growth rates, logging impacts, pioneer species, species diversity, stem hardness, Sumatra, tropical rain forest

\footnotetext{
Abbreviation

$\mathrm{DBH}$ : stem diameter at breast height

$R^{2}$ : coefficient of determination

$R G R$ : relative growth rate of $\mathrm{DBH}$
}

$P$ : significant probability

\section{INTRODUCTION}

The high species richness of tropical trees could be sustained through their diverse growth features throughout their life history (Richard, 1996; Whitmore, 1998). Understanding coexistence mechanisms allows trees to be arranged as diverse resources within a tropical forest. Classification of tree growth features, such as pioneer versus non-pioneer (Swain and Whitmore, 1988), could provide a paradigm to understand not only their life strategy but also functional characteristics of the forest as an assemblage. Turner (2001) reviewed tree growth characteristics and coordinated them on two axes of successional stage and tree size. However, classifications based on quantitative data are few (Condit et al. 1996; Gitay et al. 1999; Baker et al. 2003; Laurance et al. 2004; Nascimento et al. 2005).

A tropical rain forest continually decreases in original structural features and area under impacts such as logging and land-use conversion (Brown and Lugo, 1990; FAO, 2005), forest fires (Toma et al. 2000), and drought (Yoneda et al. 2006a; Engelbrecht et al. 2007; Neptad et al. 2007). Building a quantitative evaluation of these impacts is necessary for sustainable forest management and protection. This study aimed to classify diverse species of a hill dipterocarp forest into guilds together with their growth traits, elucidate the life strategies of guilds in relation to diverse resources in time and space, and evaluate human impacts on guild composition.

Various attributes of a tree life cycle have been studied, e.g., seed size (Davies and Ashton, 1999), growth rate (Condit et al. 2004), shade tolerance (Baker et al. 2003), wood density (Yoneda et al. 1999; King et al. 2006), reproduction age (Thomas, 1996), maximum size 
(Kohyama et al. 2003), and longevity (Lieberman et al. 1985). Nascimento et al. (2005) coordinated these various demographic traits and life-history attributes on two axes corresponding to light requirement and successional status, and tree sizes, as did Turner (2001). A reciprocal relationship between the intrinsic growth rate and maximum tree size can be considered as a spectrum of growth traits with successional status (Yamakura, 1996). Stem hardness could be a parameter related not only to physical architectural features but also physiological features such as the growth rate (Yoneda et al. 1999; Chairul and Yoneda, 2006) and wood density of stems (Thomas, 1996; King et al. 2006). Herein, we focus on three parameters for quantitative analysis of guild composition: the intrinsic growth rate, attainable maximum size, and stem hardness.

The growth rate and stem hardness of tropical trees were obtained from field observation in a hill dipterocarp forest over 6 years. An attainable maximum size of each taxon comprising several species of one genus was estimated from the size dependency of the growth rate on stem diameter. Eight guilds were determined using $2 \times 2$ classifications of the three parameters, and life strategies were examined through the distribution of diverse resources in time and space of a tropical forest. Human impacts on guild composition were assessed to compare them among forest stands experiencing different extents of disturbance.

\section{MATERIALS AND METHODS}

\section{Study site}

The study was conducted in a hill dipterocarp forest in Ulu Gadut, West Sumatra. The 6-ha site is on a sloping ridge with a maximum width of $200 \mathrm{~m}$ and an altitude of 546-654 $\mathrm{m}$ (Fig. 1). The vegetation is characterized by high species diversity, with 465 tree species over $10 \mathrm{~cm}$
DBH and a dominance of Fagaceae over Dipterocarpaceae (Nishimura et al. 2006; Appendix 2). The climate is superhumid, with large annual variance in rainfall. Severe dry weather in 1997 reduced tree growth rates and led to some mortality (Yoneda et al. 2006a). Local inhabitants collect various forest products, creating a heterogeneous stand structure within a mature stand.

We assessed the intensity of human disturbances in a 6-ha plot by measuring the tree density of large hardwood trees with a DBH over $30 \mathrm{~cm}$ and stem hardness over $60 \mathrm{~kg} \mathrm{f} \mathrm{cm}^{-1}$, which is one component of an intact stand because of the tree sizes and low growth rates (cf. Table 3) in this forest. Based on horizontal distribution, we divided this 6-ha plot into three blocks: PIN, BL-1, and BL-2 (Table 1). The PIN block was a mature stand containing many large hardwood trees (Yoneda et al. 1994), BL-1 was a selectively logged stand with many large hardwood trees remaining, and BL-2 was a stand with few large trees and included a secondary forest stand developed after clear-cutting (Yoneda et al.

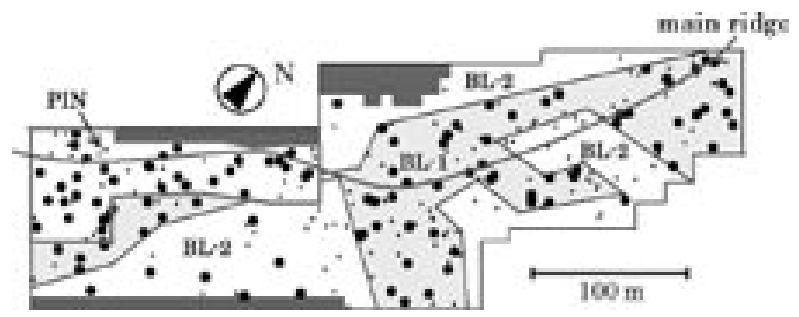

Fig. 1. Horizontal distribution of hardwood trees in terms of stem hardness $\left(H_{\mathrm{d}}\right) \geq 60 \mathrm{~kg} \mathrm{f} \mathrm{cm}^{-1}$. Closed circles and dots show big and small trees, respectively, with a boundary value of $30 \mathrm{~cm}$ DBH. Based on horizontal distribution patterns, the 6-ha plot was divided into three blocks: PIN, BL-1, and BL-2 (Table 1). Dark-shaded areas are sites without observations. The outer frame shows the 6.55-ha Pinang-pinang baru plot (Nishimura et al. 2006).

Table 1. General stand features of the three blocks in the 6-ha plot (Fig. 1). Block PIN is a mature stand, BL-2 experienced the highest impacts of logging, and BL-1 suffered an intermediate impact. $B A$ and $D N$ are the basal area and stem density, respectively, of total trees $>15 \mathrm{~cm} \mathrm{DBH}$ at the first observation in 1996. $N A$ and $N B$ are ratios (percentages) of the number available trees to total trees available for observation of stem hardness and boundary conditions of guilds, respectively. $a$ and $H^{\prime}$ are Fisher and Shannon indices of species diversity, respectively. $H^{\prime}$ has a base logarithm $=2$.

\begin{tabular}{ccccccccc}
\hline Block & $\begin{array}{c}\text { Area } \\
(\mathrm{ha})\end{array}$ & $\begin{array}{c}B A \\
\left(\mathrm{~m}^{2} \mathrm{ha}^{-1}\right)\end{array}$ & $\begin{array}{c}D N \\
\left(\mathrm{ha}^{-1}\right)\end{array}$ & $\begin{array}{c}N A \\
(\%)\end{array}$ & $\begin{array}{c}N B \\
(\%)\end{array}$ & $\begin{array}{c}\text { Species } \\
\text { number }\end{array}$ \\
\hline PIN & 1 & 37 & 368 & 91 & 34 & 130 & 79 \\
BL-1 & 2.38 & 30 & 323 & 87 & 43 & 276 & 7.3 \\
BL-2 & 2.54 & 28 & 311 & 71 & 33 & 37 & 285 & 761 \\
\hline Total & 5.92 & 30 & 326 & 81 & 37 & 7.9 \\
\hline
\end{tabular}


Table 2. Structural dimensions of common species among blocks. Figures in the upper three rows show ratios of common species between the corresponding two blocks to the total values of each block (column), and one in the "Common" row is the ratio of common species among the three blocks.

\begin{tabular}{|c|c|c|c|c|c|c|c|c|c|}
\hline \multirow[b]{2}{*}{ Block } & \multicolumn{3}{|c|}{ Species number } & \multicolumn{3}{|c|}{ Stem number } & \multicolumn{3}{|c|}{ Basal Area } \\
\hline & PIN & BL-1 & BL-2 & PIN & BL-1 & BL-2 & PIN & BL-1 & BL-2 \\
\hline PIN & 0.54 & 0.03 & 0.02 & 0.14 & 0.02 & 0.03 & 0.11 & 0.03 & 0.02 \\
\hline BL-1 & 0.06 & 0.36 & 0.44 & 0.04 & 0.10 & 0.48 & 0.05 & 0.10 & 0.42 \\
\hline BL-2 & 0.05 & 0.45 & 0.38 & 0.06 & 0.49 & 0.10 & 0.04 & 0.43 & 0.12 \\
\hline Common & 0.35 & 0.16 & 0.16 & 0.76 & 0.39 & 0.38 & 0.79 & 0.44 & 0.43 \\
\hline Total & 1.00 & 1.00 & 1.00 & 1.00 & 1.00 & 1.00 & 1.00 & 1.00 & 1.00 \\
\hline
\end{tabular}

1999).

PIN had 35\% of its total species number in common with the other two blocks, and these species had higher dominance in basal area and stem number as much as 80\% (Table 2). In BL-1 and -2, these common species decreased to $16 \%$ in species number and $40 \%$ in basal area and stem number both, while common species between these two blocks except PIN constituted as much as $45 \%$ in every dimension of each block.

\section{Tree census}

A census of all trees with a $\mathrm{DBH}>10 \mathrm{~cm}$ was repeated five times over 6 years from May 1996 to October 2002. Recruited trees were recorded at every observation. The stem hardness $\left(H_{d}\right)$ of all trees over $15 \mathrm{~cm}$ DBH was determined in 1996. This was defined as the maximum power $\left(\mathrm{kg} \mathrm{f} \mathrm{cm}^{-1}\right)$ required to pull out a nail (JISA 5508, 68 $\mathrm{mm}$ long, $3.05 \mathrm{~mm}$ diameter) driven to a depth of $60 \mathrm{~mm}$ (Yoneda, 1997). Data on $H_{d}$ were gained for $81 \%$ of the total trees over $15 \mathrm{~cm} \mathrm{DBH} \mathrm{(Table} \mathrm{1).}$

\section{Definition of the relative growth rate}

The relative growth rate of the DBH (RGR) was defined as $R G R=\ln \left(D B H_{2} / D B H_{1}\right) /\left(t_{2}-t_{1}\right)$, where $D B H_{1}$ and $D B H_{2}$ are the DBH at times $t_{1}$ and $t_{2}$, respectively. The RGR of each individual was estimated by the least-squares method, with data from the entire 6-year period. A data set of both $H_{d}$ and RGR showed high correlations with time $\left(R^{2}>0.9\right)$ for $37 \%$ (716 trees) of the total number of trees (Table 1). This data set was used for the following definition of growth parameters and tree guilds.

\section{Definition of the intrinsic growth rate and attainable maximum DBH of a taxon}

A linear model using multiple regression showed that the RGR of the 716 trees was significantly negatively correlated $\left(P=1.6 \times 10^{-16}, R^{2}=0.097\right)$ with both $\mathrm{DBH}$ and $H_{d}$, with standardized partial regression coefficients of
-0.220 for $\mathrm{DBH}$ and -0.193 for $H_{d}$. This showed that $H_{d}$ was as important a parameter of RGR as the DBH. Growth analysis at species level was, however, technically difficult because of the small number of trees per species, and we defined a group of species with similar $H_{d}$ belonging to the same genus as a taxon having similar ecological behavior (ter Steege and Harmond, 2001; Laurance et al. 2004). The RGR-DBH relationship of each taxon was approximated by a straight line with a negative slope, where

$R G R=-a D B H+b$.

The two intercepts of the straight line from Eq. (1) on the RGR and DBH axes were defined as the intrinsic growth rate $\left(R_{0}\right)$ and attainable maximum size of the $\mathrm{DBH}$ $\left(D_{\max }\right)$ of a taxon, respectively. These were obtained from $R_{0}=b$ and $D_{\max }=b / a$, respectively. For the following definition of a tree guild, we determined these two parameters in 34 taxa comprising 354 trees, with a high correlation of $R^{2}>0.09$ from Eq. (1) (Table 3).

\section{Definition of a tree guild}

A tree guild was defined as a group of taxa having similar growth traits for $R_{0}, D_{\max }$, and $H_{d}$. Eight guilds were defined by dichotomy employing average values for 34 taxa of $H_{d}=47 \pm 11 \mathrm{~kg} \mathrm{f} \mathrm{cm}^{-1}, D_{\max }=69 \pm 34 \mathrm{~cm}$, and $R_{0}=$ $0.051 \pm 0.024 \mathrm{~cm} \mathrm{~cm}^{-1} \mathrm{yr}^{-1}$. Each parameter was divided into two categories, with the average as a border value, as Soft and Hard categories for $H_{d}$, Small and Big categories for $D_{\max }$, and Slow and Fast categories for $R_{0}$. The eight guilds were determined by a $2 \times 2$ classification of these categories $\left(8=2^{3}\right)$. Symbols of guilds were derived from the initial letters of the above categories, e.g., $S B F$ denoting the Soft-Big-Fast guild (Table 3).

\section{Estimation of guild composition in a plot}

The guild composition of the 6-ha plot was examined using 1566 trees having an observed $H_{d,}$ and $81 \%$ of total trees being over $15 \mathrm{~cm} \mathrm{DBH}$ (Table 1). These trees were 
Table 3. Growth features of eight guilds and 34 taxa obtained from 354 trees in the 6-ha plot. $R_{o}, D_{\max }$, and $\mathbf{r}$ are the intrinsic growth rate, attainable maximum $\mathrm{DBH}$, and correlation coefficient from the regression of Eq. (1), respectively. $H_{d}$ is the average stem hardness of each taxon.

\begin{tabular}{|c|c|c|c|c|c|c|c|c|}
\hline \multirow[t]{2}{*}{ Guild } & \multicolumn{8}{|l|}{ Taxon } \\
\hline & Family & Genus or Species & $\begin{array}{c}\text { No. of } \\
\text { Species }\end{array}$ & $\begin{array}{l}\text { No. of } \\
\text { trees }\end{array}$ & $\begin{array}{l}D_{\max } \\
(\mathrm{cm})\end{array}$ & $\begin{array}{c}R_{0} \\
\left(\mathrm{yr}^{-1}\right)\end{array}$ & $\mathrm{r}$ & $\begin{array}{c}H_{d} \\
(\mathrm{~kg} \mathrm{f} \mathrm{cm})\end{array}$ \\
\hline \multirow{5}{*}{$\begin{array}{c}\text { soft \& } \\
\text { small \& } \\
\text { slow } \\
(\boldsymbol{S S S})\end{array}$} & Cornaceae & Mastixia trichotoma & 1 & 12 & 43 & 0.049 & -0.69 & $38 \pm 15$ \\
\hline & Icacinaceae & Gomphandra spp. & 2 & 9 & 35 & 0.041 & -0.55 & $28 \pm 3$ \\
\hline & Lecythidaceae & Barringtonia spp. & 3 & 6 & 54 & 0.026 & -0.72 & $47 \pm 9$ \\
\hline & Sapotaceae & Ganua spp. & 2 & 6 & 56 & 0.045 & -0.81 & $40 \pm 14$ \\
\hline & Styracaceae & Styrax serrulatum & 1 & 17 & 45 & 0.050 & -0.34 & $43 \pm 5$ \\
\hline \multirow{7}{*}{$\begin{array}{c}\text { soft \& } \\
\text { small \& } \\
\text { fast } \\
(\mathbf{S S F})\end{array}$} & Apocynaceae & Voacanga spp. & 2 & 6 & 32 & 0.079 & -0.66 & $30 \pm 3$ \\
\hline & Lauraceae & Beilschmiedia spp. & 2 & 5 & 28 & 0.098 & -0.80 & $38 \pm 8$ \\
\hline & Lauraceae & Endiandra spp. & 2 & 7 & 59 & 0.055 & -0.87 & $42 \pm 4$ \\
\hline & Sapotaceae & Payena spp. & 2 & 5 & 37 & 0.110 & -0.97 & $42 \pm 5$ \\
\hline & Tiliaceae & Grewia florida & 1 & 8 & 26 & 0.129 & -0.77 & $39 \pm 5$ \\
\hline & Tiliaceae & Grewia cf. florida & 1 & 10 & 40 & 0.054 & -0.69 & $40 \pm 7$ \\
\hline & Verbenaceae & Geunsia hexandra & 1 & 10 & 46 & 0.082 & -0.50 & $30 \pm 7$ \\
\hline \multirow{4}{*}{$\begin{array}{c}\text { soft \& big } \\
\text { \& slow } \\
(\boldsymbol{S B S})\end{array}$} & Burseraceae & Santiria spp. & 5 & 8 & 80 & 0.036 & -0.43 & $43 \pm 9$ \\
\hline & Dipterocarpaceae & Parashorea lucida & 1 & 5 & 148 & 0.047 & -0.60 & $43 \pm 2$ \\
\hline & Elaeocarpaceae & Elaeocarpus spp. & 6 & 8 & 77 & 0.038 & -0.81 & $45 \pm 4$ \\
\hline & Moraceae & Artocarpus spp. & 10 & 24 & 104 & 0.036 & -0.62 & $38 \pm 10$ \\
\hline \multirow{2}{*}{$S B F$} & Moraceae & Ficus spp. & 4 & 7 & 104 & 0.053 & -0.41 & $32 \pm 8$ \\
\hline & Fagaceae & Quercus oidocarpa & 1 & 6 & 104 & 0.052 & -0.79 & $42 \pm 5$ \\
\hline \multirow{6}{*}{$\begin{array}{l}\text { hard \& } \\
\text { small \& } \\
\text { slow } \\
(\boldsymbol{H S S})\end{array}$} & Dipterocarpaceae & Vatica spp. & 3 & 4 & 59 & 0.050 & -0.65 & $50 \pm 3$ \\
\hline & Ebenaceae & Diospyros spp. & 2 & 5 & 50 & 0.030 & -0.64 & $51 \pm 5$ \\
\hline & Euphorbiaceae & Aporosa spp. & 6 & 10 & 43 & 0.033 & -0.63 & $60 \pm 16$ \\
\hline & Euphorbiaceae & Cephalomappa spp. & 2 & 16 & 62 & 0.034 & -0.65 & $52 \pm 6$ \\
\hline & Euphorbiaceae & Cleistanthus glandulosus & 1 & 16 & 34 & 0.041 & -0.70 & $66 \pm 15$ \\
\hline & Sapindaceae & Xerospermum noronhianum & 1 & 8 & 69 & 0.037 & -0.59 & $54 \pm 12$ \\
\hline \multirow{2}{*}{$\boldsymbol{H S F}$} & Bombacaceae & Durio spp. & 2 & 9 & 43 & 0.051 & -0.78 & $52 \pm 9$ \\
\hline & Theaceae & Eurya spp. & 2 & 5 & 33 & 0.072 & -0.72 & $50 \pm 5$ \\
\hline \multirow{7}{*}{$\begin{array}{c}\text { hard \& big } \\
\text { \& slow } \\
(\boldsymbol{H B S})\end{array}$} & Dipterocarpaceae & Hopea dryobalanoides & 1 & 9 & 126 & 0.025 & -0.51 & $70 \pm 13$ \\
\hline & Fagaceae & Castanopsis rhamnifolia & 1 & 8 & 81 & 0.039 & -0.32 & $51 \pm 6$ \\
\hline & Fagaceae & Lithocarpus meijerii & 1 & 5 & 125 & 0.033 & -0.72 & $66 \pm 18$ \\
\hline & Fagaceae & Lithocarpus spp. & 15 & 34 & 120 & 0.036 & -0.45 & $58 \pm 13$ \\
\hline & Fagaceae & Quercus gemelliflora & 1 & 5 & 113 & 0.046 & -0.73 & $56 \pm 10$ \\
\hline & Myrtaceae & Eugenia spp. & 16 & 23 & 84 & 0.032 & -0.49 & $60 \pm 12$ \\
\hline & Sapindaceae & Nephelium spp. & 6 & 34 & 98 & 0.034 & -0.62 & $61 \pm 15$ \\
\hline $\mathrm{HBF}$ & Fagaceae & Quercus argentata & 1 & 4 & 89 & 0.072 & -0.70 & $52 \pm 3$ \\
\hline
\end{tabular}

first classified into taxa with the observed $H_{d}$ using the same procedure mentioned previously. Trees belonging to the above-mentioned 34 taxa accounted for $46 \%$ of the 1566 target trees and were $a$ priori classified into their determined guilds (Table 3 ). The $R_{0}$ and $D_{\max }$ of other taxa comprising the remaining $54 \%$ of trees were determined from the following regression obtained from the 34 taxa: $R_{0}=-0.001 H_{d}+0.102 \quad\left[\mathrm{~cm} \mathrm{~cm}^{-1} \mathrm{yr}^{-1}, \mathrm{~kg} \mathrm{f} \mathrm{cm}^{-1}\right]$ The details of this regression are shown in the results, and 
$D_{\max }=1.17 D_{m}+8.50, \quad[\mathrm{~cm}, \mathrm{~cm}]$

where $D_{m}$ is the maximum observed $\mathrm{DBH}$ of a taxon $\left(R^{2}=\right.$ 0.720 ), even though the maximum observed tree size was biased by sample sizes for estimating the attainable maximum size (Kohyama et al. 2003). Guilds of other taxa except the 34 taxa were determined from observed $H_{d}$ and estimates of $R_{0}$ and $D_{\max }$.

\section{RESULTS}

\section{Growth traits of taxa}

Growth properties of the 34 taxa were examined in terms of the intrinsic growth rate $\left(R_{0}\right)$, attainable maximum DBH $\left(D_{\max }\right)$, and stem hardness $\left(H_{d}\right)$. A significant correlation was observed among properties $(P<0.05$; Table 4), but a negative correlation was seen between $R_{0}$ and $D_{\max }$ caused by artificial analytic effects because a species group from random sampling produced a similar correlation. $R_{0}$ tended to decrease with increasing $H_{d}$, having a large variance at lower $H_{d}$ (Fig. 2). We approximated this relationship with a straight line [Eq. (2);

Table 4. Correlation among three parameters of the growth traits for 34 taxa in the 6-ha plot: intrinsic growth rate $\left(R_{o}\right)$, attainable maximum DBH $\left(D_{\max }\right)$, and stem hardness $\left(H_{d}\right)$. Figures show the correlation coefficients (bold) and significance (italics).

\begin{tabular}{cccc}
\hline parameter & $R_{0}$ & $D_{\max }$ & $H_{d}$ \\
\hline$R_{0}$ & - & 0.005 & 0.004 \\
$D_{\max }$ & $\mathbf{- 0 . 4 6 7}$ & - & 0.026 \\
$H_{d}$ & $\mathbf{- 0 . 4 7 6}$ & $\mathbf{0 . 3 8 1}$ & - \\
\hline
\end{tabular}

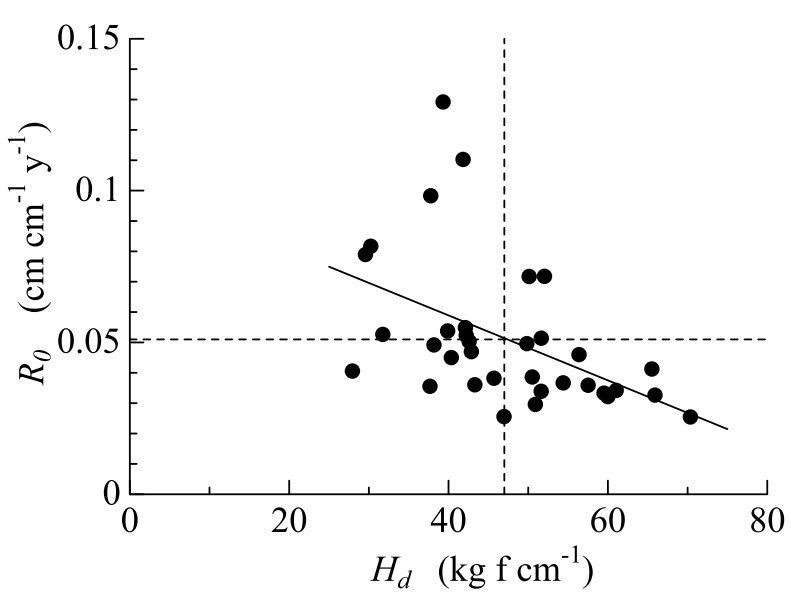

Fig. 2. Relationship between $R_{o}$ and $H_{d}$ of the $\mathbf{3 4}$ taxa. A straight line with a negative slope was obtained from Eq. (2). Vertical and horizontal broken lines show the average values: $R_{o}=0.051 \mathrm{~cm} \mathrm{~cm}^{-1} \mathrm{yr}^{-1}$ and $H_{d}=47$ $\mathrm{kg} \mathrm{f} \mathrm{cm}^{-1}$.
$\left.P=0.004, R^{2}=0.227\right]$ within the range of observed $H_{d}$, although a reciprocal relationship would be more appropriate biologically. $D_{\max }$ was positively correlated with $H_{d}$, but the significance $\left(P=0.026, R^{2}=0.145\right)$ was lower than for the two other relationships $(P<0.005$; Table 4).

\section{Species composition of a guild}

Four hundred and twenty-two identified species were used for guild determination in the 6-ha plot. SSF (SoftSmall-Fast) had the highest species diversity (142 species; Appendix 1). Grewia (Tiliaceae), Geunsia (Verbenaceae), Knema (Myristicaceae), Mallotus (Euphorbiaceae), Palaquium (Sapotaceae), Villebrunea (Urticaceae), and Litsea (Lauraceae) were dominant in this guild. Three guilds, HBS (Hard-Big-Slow), HSS (Hard-Small-Slow), and $S B F$ (Soft-Big-Fast), had 80, 71, and 60 species, respectively, with dominant species of Lithocarpus (Fagaceae), Eugenia (Myrtaceae), Nephelium (Sapindaceae), Swintonia (Anacardiaceae), Aglaia (Meliaceae), Castanopsis (Fagaceae), Hopea
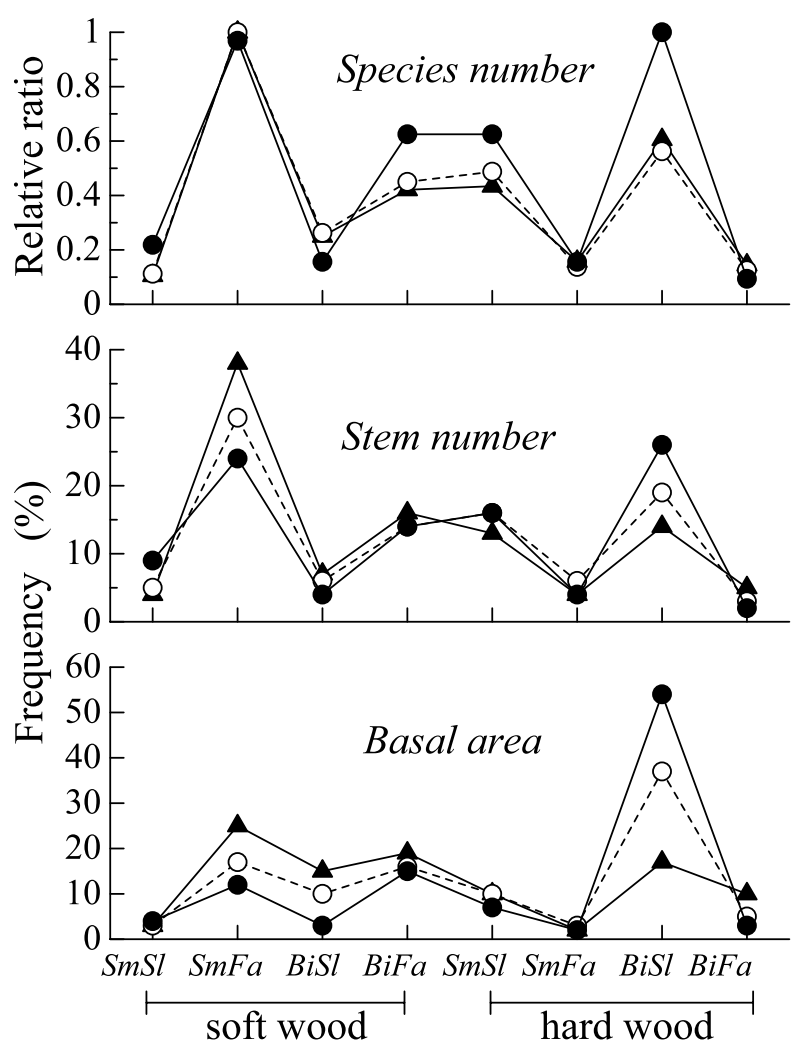

Fig. 3. Guild composition of three structural dimensions of the three blocks, PIN (O), BL-1 $(\bigcirc)$, and BL-2 $(\Delta)$, in the 6-ha plot. Symbols on the $\mathrm{x}$-axis show two categories of tree size (Small or Big) and growth rates (Slow or Fast) of the guilds. 
(Dipterocarpaceae), Pometia (Sapindaceae), and Quercus (Fagaceae) for HBS, and Cleistanthus, Cephalomappa and Aoprosa (Euphorbiaceae), and Diospyros (Ebenaceae) for $H S S$. In $S B F$, the dominant species belonged in Macaranga (Euphorbiaceae), Ficus (Moraceae), Litsea, Palaquium, and Sterculia (Sterculiaceae), Maduca (Sapotaceae), Shorea (Dipterocarpaceae), Canarium (Burseraceae), and Quercus (Fagaceae). The remaining four guilds [SSS (Soft-Small-Slow), SBS (Soft-Big-Slow), $H S F$ (Hard-Small-Fast) and HBF (Hard-Big-Fast)] had low species diversity, containing $14,25,17$, and 13 species, respectively.

\section{Guild composition of a plot}

Figure 3 shows the guild composition of the three blocks. In PIN, SSF (Soft-Small-Fast) and HBS (Hard-Big-Slow) were the major guilds, with nearly the same dominance in species number and stem density, followed by $S B F$ (SoftBig-Fast) and HSS (Hard-Small-Slow). Outstanding dominance of $H B S$ in terms of basal area was characteristic of the PIN block. BL-2 was characterized by a high dominance of $S S F$ in every structural feature. BL-1 had intermediate structural features between the other two blocks. The other four guilds ( $S S S, S B S, H S F$, and $H B F$ ) were minor components in all blocks.

\section{DISCUSSION}

\section{Growth traits of a tree taxon}

A linear relationship between the RGR and DBH of each taxon [Eq. (1)] shows that the time trend of DBH could be approximated by a simple logistic equation (Shinozaki, 1961). Two parameters of Eq. (1), $R_{0}$ and $D_{\max }$, correspond to the intrinsic growth rate $(r)$ and maximum size $(K)$ of the logistic growth curve, respectively. A negative correlation between $R_{0}$ and $H_{d}$ might suggest a trade-off between the initial volume growth rate and architectural strength under a restraint of photosynthetic products (Yoneda et al. 1999; King et al. 2006). A similar negative correlation between $R_{0}$ and $D_{\max }$, could have resulted from artificial effects of the analysis method used. However, Yamakura (1996) found the same correlation for tropical tree species using long-term monitoring data from Malaysia (Ng and Tang, 1974), and major species of a subtropical forest in Japan also showed the same correlation (Yoneda, unpublished data). These results suggest that a tree taxon used in this study likely realized the negative correlation between $R_{0}$ and $D_{\max }$ through constraints on available resources, although Kohyama et al. (2003) found no correlation between the initial growth rate in height and attainable maximum height in a tropical rain forest. Yamakura (1996) considered the negative correlation as the result of a spectrum of growth traits of tropical tree species under an $r$ - $K$ life strategy model (MacArthur and Wilson, 1967; Pianka, 1972). Condit et al. (2004) and Nascimento et al. (2005) also found a significant correlation among several demographic parameters, including the growth rate, maximum diameter, and wood density in Amazonian trees. These findings support the theory whereby pioneer and climax species show opposite growth traits (Swain and Whitmore, 1988; Baker et al. 2003).

The simple logistic equation shows that the time $\left(T_{D \max / 2}\right)$ to satisfy $\mathrm{DBH}=D_{\max } / 2$ on the growth curve is $\ln \left(D_{\max } / D_{0}-1\right) / R_{0}$, where $D_{0}$ is the initial DBH at $t=0$. When we examined the relationships between $D_{\max }$ and $T_{D \max / 2}$, about 83 major taxa (Appendix 1) showed dispersed distribution on these coordinates (Fig. 4). This reveals habitat segregation in time and space, when $T_{D \max / 2}$ is regarded as not only a chronological parameter but also a spatial parameter because of the mosaic stand structure in a mature forest consisting of different phases. The diversity of intrinsic growth rates is considered a common evolutionary product of plants and animals that adapt to given resources in a biome (Arendi, 1997). In the present study, the wide range and continuum of intrinsic growth rates of the 83 taxa was related to a large space-time variance of resource availability in a mature tropical rain forest, with wide variations in the attainable maximum size and stem hardness.

\section{Life strategies of guilds}

Four major guilds were created using a mechanical process of classification. A higher correlation was observed between $R_{0}$ and $D_{\max }$ than between $R_{0}$ and $H_{d}$, which produced two prominent guilds, $S S F$ (Soft-SmallFast) and HBS (Hard-Big-Slow), together with two other major guilds, SBF (Soft-Big-Fast) and HSS (Hard-SmallSlow).

$S S F$ contains not only typical pioneer species, but also highly diverse species (Appendix 1,2). Kohyama and Suzuki (1994) found that Grewia florida (SSF) and Mastixia tricotoma (SSS) were shade-intolerant and that two species in the HSS guild, Cleistanthus glandulosus and Gonystylus foerbesii, were shade-tolerant based on horizontal distribution patterns in the PIN block. These results suggest opposite responses to light between $S S F$ and $H S S$, particularly at the seedling stage. HSS was characterized by long tree longevity with slow growth rates under shade conditions, in comparison to $S S F$. SSF 

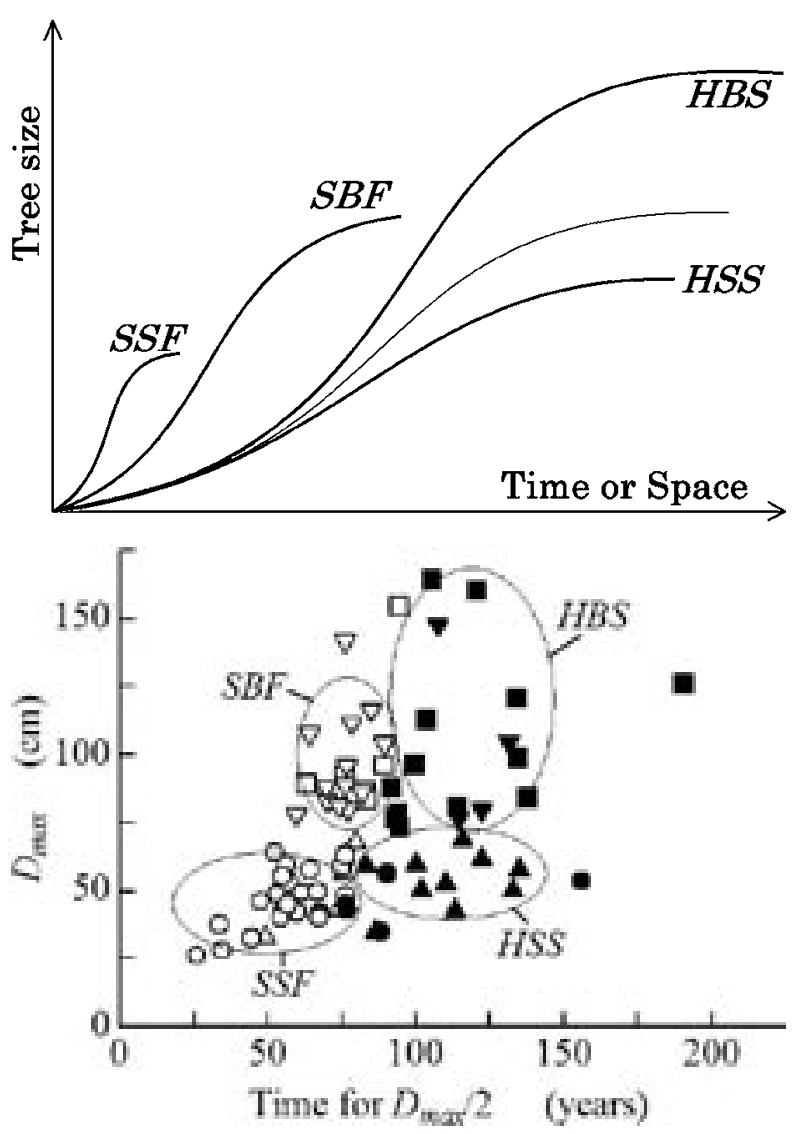

Fig. 4. Bottom: Relationship between an attainable maximum DBH $\left(D_{\max }\right)$ and time required for $D_{\max } / 2$ growth of 83 major taxa in the 6 -ha plot where $D_{o}=1 \mathrm{~cm}$ (Appendix 1). SSF $=\bigcirc$, $S S S=0, S B F=\nabla, S B S=\nabla, H S F=\triangle, H S S$ $=\Delta, H B F=\square$, and $H B S=\square$. Top: Schematic diagram of growth curves for the major four guilds based on simple logistic growth.

showed a clear positive correlation between the maximum tree size and longevity among taxa within the guild, when $T_{D \max / 2}$ was taken as a parameter of longevity (Fig. 4). This might be a gradient of adaptive growth traits closely associated with reproductive traits under a disturbance regime (Thomas, 1996; Chairul and Yoneda, 2006). Some genera of Dipterocarpaceae were also classified into HSS (Appendix 1), although their biased population structure, which lacks mature-sized trees due to logging, means that this result should be interpreted with caution (Nishimura et al. 2006).

The SBF (Soft-Big-Fast) guild has some advantages under intermediate disturbance conditions (Connell, 1978). It included many dominant secondary forest genera such as Litsea, Ficus, Palaquium, and Sterculia, as well as some typical pioneer trees with large $D_{\max }$ (Yoneda, 2000; Yoneda et al. 2006b). The average $D_{\max }$ of $S B F$ was significantly smaller than that of $H B S(P<0.001)$, but this guild included some species with $D_{\max }>100 \mathrm{~cm}$ such as Shorea lepidota and Canarium vulgare. Their growth traits might judge them as being "heliotrophic climax species" (Yamakura, 1996), like Shorea leprosula in Malaysia. These species would be useful in silviculture together with some species of $H B F$ such as Dysoxylum excelsum.

$H B S$ was composed of major species in emergent and dominant layers in the PIN block. Hard wood could be a useful architectural property for very tall emergent trees and canopy trees with a large crown in dominant layers such as fagaceous trees. This guild had large variance in $D_{\max }$ without a clear correlation between $D_{\max }$

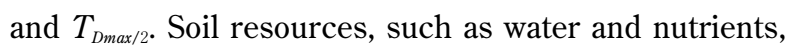
and not light resources, might be the major factors for this variance.

Figure 4 coordinates the four guilds on two axes of time and space. That is, the dominance of canopy trees would successively change from $S S F$ to $H B S$ through $S B F$ under stable environmental conditions because of their different $D_{\max }$, and $H S S$ could complete their long life span as understory species because of their high shade tolerance (Baker et al. 2003).

Turner (2001) reviewed the growth traits of tropical trees and classified them into four guilds along two major axes expressing successional status (Pioneer vs. Climax) and tree size (Small vs. Big). Our four major guilds, $S S F$, $H B S, S B F$, and $H S S$, correspond well to Turner's four guilds, Small Pioneer, Climax, Large Pioneer, and Understory, respectively. Nascimento et al. (2005) successfully classified tree species of the Amazonian rain forest into four similar experimental guilds.

Four other minor guilds, $S S S, S B S, H S F$, and $H B F$, were related by a large variance in $R_{0}-D_{\max }$ and $R_{0}-H_{d}$ relationships, and could be evaluated as ecological interfaces among the four major guilds. These guilds had low species diversity, although they included some taxa with high dominance (Appendix 1). We assessed their traits in relation to the four major guilds based on their $D_{\max }$ and $T_{D \max / 2}$ coordinates (Fig. 4). Two taxa of SSS (SoftSmall-Slow), Mastixia and Styrax, were close to SSF; four taxa of $S B S$ (Soft-Big-Slow) were close to $H B S$; one taxon of $H S F$ (Hard-Small-Fast), Durio, was close to SSF; and two taxa of HBF (Hard-Big-Fast), Quercus and Dysoxylum, were close to $S B F$. These four minor guilds might play important roles as a major guild under certain environmental conditions in a new disturbance regime in the future. 


\section{Human impacts on guild composition}

Human impacts were examined through a comparison of guild composition among the three blocks, based on the assumption that PIN $<$ BL-1 < BL-2 showed a gradient of human disturbance, although the complex topographic conditions would also be an important parameter of the habitat (Ito et al. 2003; Nishimura et al. 2008). Blocks 1 and 2 were characterized by a higher dominance of $S S F$ (Soft-Small-Fast) over HBS (Hard-Big-Slow) in species number in comparison with the PIN block (Fig. 3). Common species between BL-1 and BL-2 accounted for about $45 \%$ of total species number (Table 2), and $S S F$ was a dominant guild in both. Higher species richness of $S S F$ could be related to higher diversity of habitat for these pioneer trees following logging activity (Yoneda et al. 1999). Geunsia pentandra (Verbenaceae) is the most representative in secondary vegetation (FDMPIM, 1978), including fallow fields after slash-and-burn practices (Hashimoto et al. 2007), Symplocos fasciculata (Symplocaceae) is found in primary and secondary forests (Nooteboom, 1977), and Grewia florida (Tiliaceae) is a common species in gaps in primary stands in this plot (Kohyama and Suzuki, 1994). These two blocks share the diverse habitats of $S S F$. A similar guild composition in species number between BL-1 and BL-2 could result from similar habitat composition at the guild level with high diversity at the species level, and different intensities of logging impact between them were related to different guild compositions in the dimensional features of stem number and basal area (Fig. 3).

Low species richness in HBS (Hard-Big-Slow) over $S B F$ (Soft-Big-Fast) and HSS (Hard-Small-Slow) was another property at BL-1 and -2, and was probably related to selective logging of dipterocarps as the major target species (Nishimura et al. 2006). Three of the four remaining major dipterocarps showed a biased distribution to the PIN and BL-1 blocks (Nishimura et al. 2008 ) belonging to $H B S$, and another dipterocarp of the SBS guild, Parashorea lucida, had major habitats in BL-1 and BL-2. The different distributional patterns in $H B S$ and $S B S$ in the present dipterocarps suggest different impacts of logging among the three blocks rather than an influence of topographic conditions.

High dominance and high species diversity of Fagaceae is a floristic feature of this forest (Fujii et al. 2006; Nishimura et al. 2006). Five of the ten major fagaceous species had a random distribution, presumably caused by biotic interactions such as the high dispersal ability of seeds, while another five species were aggregated (Nishimura et al. 2008). All five spatially aggregated species belonged to $H B S$ and had biased distributions to the PIN and BL-1 blocks. Four (Lithocarpus histrix, L. lucudus, L. macphailii, and Quercus oidocarpa) of the five randomly distributed species were mainly found in BL-1 and BL-2, and three of these four (except L. macphailii) belonged to softwood guilds. This habitat segregation between soft- and hardwood guilds of these fagaceous trees might be caused by the same factors as for the dipterocarps.

Canopy trees of a mature rain forest in this area have suffered high mortality since the latter half of 1990s because of dry weather and logging (Yoneda et al. 2006). This has led to rapid reduction and extinction of species of $H B S$ in the fragmented hill dipterocarp forest. Luarance et al. (2004) also found recent dynamic and large-scale changes in guild composition in undisturbed Amazonian forests. Thus, building a quantitative evaluation of changes in these rain forests is critical for sound management and protection, although clarifying the mechanisms quantitatively is difficult because of the complex impacts of both human and natural disturbances.

ACKNOWLEDGMENTS We thank the late Dr. Syunzo Kawamura and Dr. Ryoichi Ogushi for their support under the JICA Project, Field Biology Research and Training (FBRT), and many colleagues and students in Japan and Indonesia for their collaboration during field observations. This study was financially supported by the Japan International Cooperation Agency (JICA) through the FBRT project (1994-1996), and the Ministry of Education, Culture, Sports, Science and Technology, Japan, through Grants-in-Aid for Overseas Scientific Surveys (2000-2003).

\section{REFERENCES}

Arendi, J.D. 1997. Adaptive intrinsic growth rates: an integration across taxa. The Quarterly Review of Biology, 72: 149-177.

Baker, T.R., Swaine, M.D. \& Burslem, D.F. 2003. Variation in tropical forest growth rates: combined effects of functional group composition and resource availability. In: Perspectives in plant ecology, evolution and systematics 16: 21-36, Urban \& Fisher.

Brown, S. \& Lugo, A.E. 1990. Tropical secondary forest. Journal of Tropical Ecology, 6: 1-32.

Chairul \& Yoneda, T. 2006. Leaf longevity of tropical shrub species in an open forest in Sumatra. Tropics, 15: $201-207$.

Condit, R., Hubbell, S.P. \& Foster, R.B. 1996. Assessing 
the response of plant functional types to climatic change in tropical forests. Journal of Vegetation Science, 7: 405-416.

Condit, R., Laurance, W.F., Nascimento, H.E.M., Laurance, S.G., D’ Angelo, S. \& Andrade, A. 2004. Inferred longevity of Amazonian rainforest trees based on a long-term demographic study. Forest Ecology and Management, 190: 131-143.

Connell, J.H. 1978. Diversity in tropical rain forests and coral reefs. Science, 199: 1302-1310.

Davies, S.J. \& Ashton, P.S. 1999. Phenology and fecundity in 11 sympatric pioneer species of Macaranga (Euphorbiaceae) in Borneo. American Journal of Botany, 86: 1786-1795.

Engelbrcht, B.M., Comita, L.S., Condit, R., Kursar, T.A., Tyree, M.T., Turner, B.L. \& Hubbell, S.P. 2007. Drought sensitivity shapes species distribution patterns in tropical forests. Nature, 447: 80-82.

FAO (Food and Agriculture Organization of the United Nations) 2005. FAO Forestry Paper 147: Global Forest Resources Assessment 2005.

FDMPIM (Forest Department Ministry of Primary Industries Malaysia) 1978. Geunisa B1. In: Ng, F.S.P. Ng (Ed.) Tree flora of Malaysia 3: 305, Logman, Kuala Lumpur.

Fujii, S., Nishimura, S. \& Yoneda, T. 2006. Altitudinal distribution of Fagaceae in West Sumatra. Tropics, 15: 153-163.

Gitay, H., Noble, I.R. \& Connell, J.H. 1999. Deriving functional types for rain-forest trees. Journal of Vegetation Science, 10: 641-650.

Hashimoto, T., Tange, T., Masumoto, M., Yagi, H. \& Kojima, K. 2007. Early successional process of a fallow forest in East Kalimantan, Indonesia. Tropics, 16: 253-259.

Ito, A., Yamakue, T., Ohkubo, T., Kanzaki, M., Palmiotto, P.A., Lafrankie, J.V., Ashton, P.S. \& Lee, H.S. 2003. Importance of topography and soil texture in the spatial distribution of two sympatric dipterocarp trees in a Bornean rainforest. Ecological Research, 18: $307-320$.

King, D.A., Davies, S.J., Tan, S. \& Noor, N.S.M. 2006. The role of wood density and stem support costs in the growth and mortality of tropical trees. Journal of Ecology, 94: 670-680.

Kohyama, T. \& Suzuki, E. 1994. Spatial distribution pattern of reproductive tree species in a foothill rain forest in West Sumatra. Tropics, 4: 1-15.

Kohyama, T., Suzuki, E., Partomihardjo, T., Yamada, T. \& Kubo, J. 2003. Tree species differentialtion in growth, recruitment and allometry in relation to maximum height in Bornean mixed dipterocarp forest. Journal of Ecology, 91: 797-806.

Laurance, W.F., Oliveira, A.A., Laurance, S.G., Condit, R., Nascimento, H.E.M., Scanchez-Thorin, A.C., Lovejoy, T.E., Andrade, A., D’ Angelo, S., Ribeiro, J.E. \& Dick, C.W. 2004. Pervasive alteration of tree communities in undisturbed Amazonian forests. Nature, 428: 171-174.

Lieberman, D., Lieberman, M., Hartshorn, G.S. \& Peralta, R. 1985. Growth rates and age-size relationships of tropical wet forest in Costa Rica. Journal of Tropical Ecology, 1: 97-109.

MacArther, R.H. \& Wilson, E.O. 1967. The theory of Island Biogeography. Princeton University Press, Princeton.

Nascimento, H.E.M., Laurance, W.F., Condit, R., Laurance, S.G., D’ Angelo, S. \& Andra, A.C. 2005. Demographic and life-history correlates for Amazonian trees. Journal of Vegetation Science, 16: 625-634.

Neptad, D.C., Tohver, I.M., Ray, D., Moutinho, P. \& Cardinot, G. 2007. Mortality of large trees and liana following experimental drought in an Amazon forest. Ecology, 88: 2259-2269.

Ng, F.S.P. \& Tang, H.T. 1974. Comparative growth rates of Malaysian trees. Malayan Forester, 37: 2-23.

Nishimura, S., Yoneda, T., Fujii, S., Mukhtar, E., Abe, H. \& Kanzaki, M. 2006. Factors influencing the floristic composition of a hill forest in West Sumatra. Tropics, 15: 165-175.

Nishimura, S., Yoneda, T., Fujii, S., Mukhtar, E. \& Kanzaki, M. 2008. Spatial patterns and habitat associations of Fagaceae in a hill dipterocarp forest in Ulu Gadut, West Sumatra. Journal of Tropical Ecology, 24: 535-550.

Nooteboom, H.P. 1977. Symplocos fasciculata. Flora Malesiana, (Ser. I) 8: 259-260.

Pianka, E.R. 1972. $r$ and $K$ selection or $b$ and $d$ selection? The American Naturalist, 106: 581-588.

Richard, P.W. 1996. The tropical rain forest: An ecological study. (Second edition) Cambridge University Press, Cambridge.

Shinozaki, K. 1961. Logistic theory for plant growth. Thesis of a doctor degree, Kyoto University. (in Japanese)

Swain, M.D. \& Whitmore, T.C. 1988. On the definition of ecological species groups in tropical rain forest. Vegatatio, 75: 81-86.

ter Steege, H. \& Harmond, D.S. 2001. Character 
convergence, diversity, and disturbance in tropical rain forest in Guyana. Ecology, 82: 3197-3212.

Toma, T., Matius, P., Hastaniah, Kiyono, Y., Watanabe, R. \& Okimori, Y. 2000. Dynamics of burned lowland dipterocarp forest stands in Bukit Soeharto, East Kalimantan. In: Rainforest Ecosystems of East Kalimantan (ed. Guhardja, E., Fatawi, M., Sutisna, M., Mori, T. \& Ohta, S.) Ecological Studies 140: Pp.106-119. Springer-Verlag Tokyo.

Thomas, S.C. 1996. Relative size at onset of maturity in rain forest trees: a comparative analysis of 37 Malayan species. OIKOS, 76: 145-154.

Turner, I.M. 2001. The ecology of trees in the tropical rain forest. Cambridge Tropical Biology Series, Cambridge University Press, Cambridge.

Whitmore, T.C. 1998. An introduction to tropical rain forests. Second edition. Oxford University Press, Oxford.

Yamakura, T. 1996. Primary production and nutrient cycling of a tropical rain forest. In: Iwatsubo, G. (Ed.), Forest Ecology 258-291. Buneido-Shuppan, Tokyo. (in Japanese)

Yoneda, T. 1997. Instruction for measurement of hardness of stem wood in the field. Tropical Ecological Letters, 27: 17-20. (in Japanese)

Yoneda, T. 2000. Vegetational structure of the Minagkabau's village, West Sumatra, Indonesia. Research Report of the Japan Center for Area Studies (JCAS), 3: 49-83. (in Japanese with English summary)

Yoneda, T., Ogino, K. Kohyama, T., Tamin, R., Syabuddin and Rahman, M. 1994. Horizontal variance of stand structure and productivity in a tropical foothill rain forest, West Sumatra. Tropics, 4: 17-33.

Yoneda, T., Kohyama, T. \& Hotta, M. 1999. Successive changes of structure and productivity of tropical secondary forest stands after clear cutting in West Sumatra, Indonesia. Tropics, 8: 357-375.

Yoneda, T., Mizunaga, H., Nishimura, S., Fujii, S., Mukhtar, E., Hotta, M. \& Ogino, K. 2006a. Impacts of recent dry weather on a tropical rain forest in Sumatra with special reference to stand dynamics during the last two decades. Tropics, 15: 177-187.

Yoneda, T., Mizunaga, H., Nishimura, S., Fujii, S. \& Tamin, R. 2006b. Stand structure and dynamics of a tropical secondary forest - A rural forest in West Sumatra, Indonesia. Tropics, 15: 189-199. 
Appendix 1. Guild composition of the 6-ha plot and major taxa with high relative dominance of over $0.5 \%$ as the sum of the relative values of basal area (BA) and tree number (TN).

\begin{tabular}{|c|c|c|c|c|c|c|}
\hline \multirow{2}{*}{$\begin{array}{l}\text { Guild (total sp. } \\
\text { number) }\end{array}$} & \multicolumn{6}{|c|}{ Taxon } \\
\hline & Family & Genus & $\begin{array}{l}\text { Major } \\
\text { species }\end{array}$ & $\begin{array}{c}\text { No. of } \\
\text { Species }\end{array}$ & $\begin{array}{l}B A \\
(\%)\end{array}$ & $\begin{array}{l}\mathrm{TN} \\
(\%)\end{array}$ \\
\hline \multirow{6}{*}{$S S S$ (14spp) } & Clusiaceae & Garcinia & G. celebica. & $\frac{n}{2}$ & 0.3 & 0.4 \\
\hline & Cornaceae & Mastixia & M. trichotoma & 1 & 0.6 & 1.2 \\
\hline & Icacinaceae & Gomphandra & G. pseudojavanica & 3 & 0.2 & 0.6 \\
\hline & Lecythidaceae & Barringtonia & B. macrostachya & 4 & 0.3 & 0.6 \\
\hline & Sapotaceae & Ganua & G. palembanica & 2 & 0.6 & 0.6 \\
\hline & Styracaceae & Styrax & S. serrulatum., S. paralleluneurum & 2 & 1.3 & 2.7 \\
\hline & Actinidaceae & Sauraria & S. nudiflora & 1 & 0.3 & 0.3 \\
\hline & Annonaceae & Polyalthia & P. lateriflora & 3 & 0.3 & 0.5 \\
\hline & Apocynaceae & Voacanga & V. foetida. & 2 & 0.7 & 0.9 \\
\hline & Euphorbiaceae & Endospermum & E. moluccanum & 1 & 0.2 & 0.4 \\
\hline & Euphorbiaceae & Macaranga & M. pruinosa & 4 & 0.3 & 0.5 \\
\hline & Euphorbiaceae & Mallotus & M. paniculatus, $M$. retinoides & 5 & 0.7 & 1.6 \\
\hline & Flacourtiaceae & Hydnocarpus & H. kunstleri & 3 & 0.2 & 0.4 \\
\hline & Icacinaceae & Platea & P. excelsa & 1 & 0.4 & 0.5 \\
\hline & Lauraceae & Beilschmiedia & B. bangkae & 2 & 0.4 & 0.6 \\
\hline & Lauraceae & Cryptocarya & C. nitens & 6 & 0.1 & 0.4 \\
\hline & Lauraceae & Endiandra & E. rubescens & 1 & 0.8 & 0.6 \\
\hline & Lauraceae & Litsea & L. mappacea, L. resinosa & 4 & 0.6 & 1.1 \\
\hline$S S F(142 \mathrm{spp})$ & Melastomaceae & Pternandra & $P$ carulescens, $P$ cordata & 3 & 0.2 & 0.5 \\
\hline & Myristicaceae & Knema & K. hookeriana & 9 & 0.5 & 0.9 \\
\hline & Olacaceae & Strombosia & S. javanica & 1 & 0.2 & 0.4 \\
\hline & Rubiaceae & Pleiocarpidia & P. enneandra & 1 & 0.2 & 0.6 \\
\hline & Sapotaceae & Palaquium & $P$. hexandrum, $P$. rostratum & 5 & 0.7 & 1.3 \\
\hline & Sapotaceae & Payena & P. acuminata & 2 & 0.7 & 0.7 \\
\hline & Symplocaceae & Symplocos & S. faciculata & 2 & 0.6 & 1.4 \\
\hline & Thymelaceae & Aquilaria. & A. malaccensis & 1 & 0.4 & 0.4 \\
\hline & Tiliaceae & Grewia & G. florida & 1 & 0.4 & 1.1 \\
\hline & Tiliaceae & Grewia & G. $c f$. florida & 1 & 1.4 & 2.1 \\
\hline & Urticaceae & Pipturus & $P$ argenteus & 2 & 0.3 & 0.6 \\
\hline & Urticaceae & Villebrunea & V. rubescens & 2 & 0.5 & 1.7 \\
\hline & Verbenaceae & Geunsia & G. hexandra & 1 & 1.5 & 2.0 \\
\hline & Burseraceae & Santivia & S. laevigata, S. apiculata & $\frac{1}{5}$ & 1.3 & 1.0 \\
\hline & Dipterocarpaceae & Parashorea & P. lucida & 1 & 2.4 & 0.8 \\
\hline SBS (25spp) & Elaeocarpaceae & Elaeocarpus & E. glaber, E. littoralis & $\begin{array}{l}1 \\
9\end{array}$ & $\begin{array}{l}2.4 \\
1.0\end{array}$ & 1.2 \\
\hline & Moraceae & Artocarpus & A. lancifolius, $A$. rigidus & 9 & 6.1 & 2.9 \\
\hline & Anacardiaceae & Buchanania & B. arborescens & 1 & 0.7 & 0.1 \\
\hline & Asteraceae & Vernonia & V. arborea & 1 & 0.6 & 0.3 \\
\hline & Burseraceae & Canarium & C. vulgare & 3 & 1.3 & 0.4 \\
\hline & Dipterocarpaceae & Shorea & S. lepidota & 4 & 1.0 & 0.6 \\
\hline & Euphorbiaceae & Macaranga & M. gigantea., M.hypoleuca, M. triloba & 3 & 2.6 & 3.2 \\
\hline & Euphorbiaceae & Mallotus & M. laevigata & 1 & 0.2 & 0.6 \\
\hline & Fagaceae & Quercus & Q. oidocarpa & 2 & 1.2 & 0.6 \\
\hline$S B F(60 \mathrm{spp})$ & Lauraceae & Litsea & L. cubeba, L. robusta & 10 & 1.1 & 1.2 \\
\hline & Lauraceae & Phoebe & P. ellipitica & 3 & 0.4 & 0.3 \\
\hline & Magnoliaceae & Magnolia & M. gigantifolia & 1 & 0.3 & 0.3 \\
\hline & Moraceae & Ficus & $F$ ribes & 9 & 1.2 & 1.7 \\
\hline & Sapindaceae & Lepisanthes & L. tetraphylla & 1 & 0.3 & 0.3 \\
\hline & Sapotaceae & Madhuca & M. sericea & 4 & 0.9 & 1.3 \\
\hline & Sapotaceae & Palaquium & P. obovatum & 2 & 1.8 & 2.1 \\
\hline & Sterculiaceae & Sterculia & S. rubiginosa & 7 & 0.8 & 1.1 \\
\hline & Dipterocarpaceae & Hopea & Hopea $s p$ & 2 & 0.2 & 0.4 \\
\hline & Dipterocarpaceae & Shorea & S. atrinervosa, $S$. maxiwelliana & 2 & 0.4 & 0.6 \\
\hline & Dipterocarpaceae & Vatica & V. cf.ridleyana & 4 & 0.4 & 0.3 \\
\hline & Ebenaceae & Diospyros & D. sumatrana & 4 & 0.3 & 0.9 \\
\hline USC & Euphorbiaceae & Aporusa. & A. antenifera & 7 & 0.5 & 0.9 \\
\hline HSS (/1spp) & Euphorbiaceae & Cephalomappa & C. malloticarpa & 2 & 1.5 & 1.5 \\
\hline & Euphorbiaceae & Cleistanthus & C. glandulosus & 2 & 2.0 & 3.8 \\
\hline & Meliaceae & Dysoxylum & D. caulostachyum & 3 & 0.2 & 0.4 \\
\hline & Rubiaceae & Nauclea & N. crytopoda, purpurascens & 2 & 0.2 & 0.4 \\
\hline & Sapindaceae & Xerospermum & $X$. noronhianum & 1 & 0.4 & 0.6 \\
\hline & Alangiaceae & Alangium & A. javanicum (Bl.) King. & 3 & 0.5 & 1.1 \\
\hline & Bombacaceae & Durio & D. griffithii., D. zibethinus & 3 & 0.7 & 1.5 \\
\hline$H S F(17 \mathrm{spp})$ & Euphorbiaceae & Mallotus & $M$. penangensis & 3 & 0.3 & 0.4 \\
\hline & Theaceae & Eurya & E. acuminata & 2 & 0.2 & 0.7 \\
\hline & Anacardiaceae & Swintonia & S. schwenkii & 2 & 5.6 & 1.0 \\
\hline & Clusiaceae & Calophyllum & C. soulatri & 1 & 0.8 & 0.3 \\
\hline & Dipterocarpaceae & Hopea & H. dryobalanoides & 1 & 1.0 & 0.9 \\
\hline & Euphorbiaceae & Drypetes & D. negecta & 2 & 0.3 & 0.4 \\
\hline & Fagaceae & Castanopsis & C. rhamnifolia & 2 & 1.4 & 1.0 \\
\hline & Fagaceae & Lithocarpus & L. javensis, L. meijerii & 19 & 9.8 & 4.1 \\
\hline$H B S$ (80spp) & Fagaceae & Quercus & Q. gemelliflora & 1 & 1.2 & 0.4 \\
\hline & Flacourtiaceae & Ryparosa & R. kunstleri & 2 & 0.5 & 0.4 \\
\hline & Lecythidaceae & Planchonia & P. valida & 1 & 0.9 & 0.1 \\
\hline & Meliaceae & Aglaia & A. ganggo & 13 & 0.8 & 1.4 \\
\hline & Myrtaceae & Eugenia & E. lineata, E. clavimyrtus & 22 & 3.2 & 4.0 \\
\hline & Sapindaceae & Nephelium & N. juglandifolium, N. mutabile & 7 & 4.7 & 3.1 \\
\hline & Sapindaceae & Pometia & $\begin{array}{l}\text { P. alnifolia } \\
\text { Plac }\end{array}$ & 3 & 0.7 & 0.6 \\
\hline & Euphorbiaceae & Blumeodendron & B. tokbrai & 1 & 0.6 & 0.3 \\
\hline & Euphorbiaceae & Ptychopyxis & P. bacciformis & 1 & 0.5 & 0.3 \\
\hline$H R F(13 \mathrm{snn})$ & Fagaceae & Quercus & Q. argentata & 1 & 1.2 & 0.4 \\
\hline HBF (13spp) & Lythraceae & Lagerstroemia & L. ovalifolia & 1 & 0.8 & 0.1 \\
\hline & Meliaceae & Dysoxylum & D. excelsum & 8 & 2.2 & 1.7 \\
\hline & Sapotaceae & Palaquium & P. gutta & 1 & 0.7 & 0.8 \\
\hline
\end{tabular}




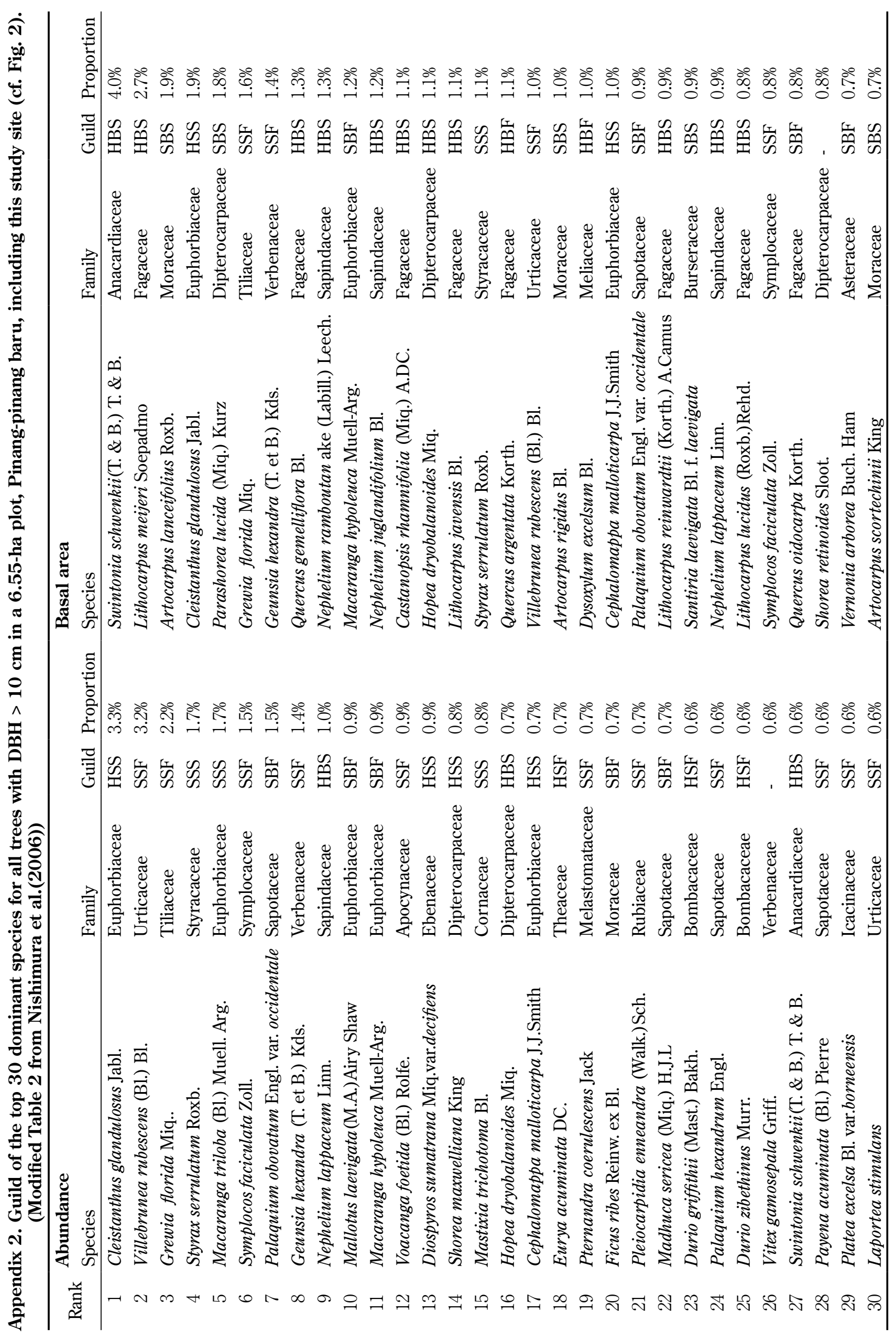

